\title{
Pakistani Nationalism and the State Marginalisation of the Ahmadiyya Community in Pakistan
}

\author{
Sadia Saeed \\ University of Michigan, Ann Arbor, USA
}

\begin{abstract}
This paper examines the relationship between nationalism, state formation, and the marginalisation of national minorities through an historical focus on Pakistani state's relationship with the Ahmadiyya community, a self-defined minority sect of Islam. In 1974, a constitutional amendment was enacted that effectively rendered the Ahmadiyya community a non-Muslim minority, in spite of claims by the community that it was Muslim and hence not a minority. This paper attempts to account for this anti-Ahmadiyya state legislation by arguing that the genealogy of the idea of a Pakistani state is key for understanding the politics of exclusion of the Ahmadiyya community from 'Muslim citizenship' - that is, who is and isn't a Muslim.
\end{abstract}

\section{Introduction}

This paper explores the relationship between nationalism, state formation, and the marginalisation of national minorities. In the literature on the nation and nationalism, the relationship between state formation and nationalist exclusions is often under-theorised, with the implicit assumption made that processes of nation building occur independently of the construction of state institutions. Many works have shown the pitfalls of this neglect by demonstrating that the articulation of nationalist ideologies, and the processes which take place in the national community as a result of such nationalisms, are either aided by, or are articulated in response to, the formation of state institutions and practices of social closure (Brubaker 1992; Balibar 2004; Omi and Winant 1994).

In this paper, I revisit the debate on the relationship between nationalism and state-formation through a consideration of the Pakistani state's historically 
varying relationship with its Islamic politico-religious identity. The empirical focus of this paper is the historical background of the second constitutional amendment of Pakistan, enacted in 1974, which in effect rendered the Ahmadiyya community, a self-identified minority sect of Islam with roughly 2 million adherents in Pakistan, outside the pale of Islam by institutionalising its status as a 'non-Muslim minority', despite the insistence of the Ahmadiyya community that it was Muslim, and therefore not a non-Muslim minority. ${ }^{1}$ This amendment is a critical chapter in the history of state formation in modern Pakistan as it gave a new definition of the national community by equating the nation with Islam.

In what follows, I attempt to achieve the following three objectives: first, I will briefly lay out the theoretical core of the paper with regard to the relationship between states and exclusionary dimensions of nationalism. Second, I will give a historical account of the genealogy of what is popularly termed 'the Ahmadi question' in Pakistan by identifying three crucial moments in the state's relationship with the community. Lastly, I will examine the state's response to anti-Ahmadiyya demands in 1974 when the second constitutional amendment was enacted. In this paper, I seek to account for how and why the Pakistani state forcibly evicted the Ahmadiyya sect from the community of Islam. I suggest that the genealogy of the idea of the Pakistani state is key for understanding the politics of exclusion of the Ahmadiyya community from 'Muslim citizenship', that is, who is and isn't a Muslim. The shifting bases of Pakistani nationalism from 1954 to 1974 led to changes in the Pakistani state, which in turn led to the construction of new social imaginaries through which the very idea of the Pakistani nationstate was discursively and institutionally (re-) articulated.

\section{State Theory and the Formation of National Identities}

Nationalism is typically viewed normatively as a necessary evil in the modern world, sanctioning as it does various forms of exclusions and hierarchies, both internal and external to the territorial state (Kedourie 1960; Chatterjee 1993; Balibar 2004). In contrast to this view, another differentiates between two versions of nationalism: liberal, or civic nationalism vs. illiberal, ethnic, or religious nationalism (Kohn 1944; Plamenatz 1976; Ignatieff 1994). While the former is found in open, pluralistic societies, and is characterised by a commitment to values of liberty, equality, sanctity of individual rights, and democracy, regardless of class or ethnic identifications, illiberal nationalism is found in closed, authoritarian societies and rejects the principles of Western Enlightenment grounded in rationality, favouring instead identifications with class, ethnic or racial communities. 
Both these schools of thought give primacy to the form and content of nationalisms, thereby locating the evils present in nationalisms in the ideological nature of their content. In all these theories, the existence of the state is implicitly taken for granted and is the necessary condition for the emergence of nationalisms. This lack of theorisation on the relationship between nationalcultural formations and state-building, however, is suspect, and was also present in neo-Weberian theories of state formation that emerged in the late 1970s and 1980s (e.g. Tilly 1985; Skocpol 1979; Mann 1986). Drawing a sharp distinction between the cultural and the political spheres, neo-Weberian theories implicitly rendered the former as subservient to the latter.

However, this line of theorisation occludes the ways in which processes of state-formation occur through appropriations of cultural idioms (Anderson 1991; Appadurai 1981; Brubaker 1992); and second, it ignores that the state itself is a social construction and a cultural formation (Hansen and Stepputat 2005; Steinmetz 1999). The very elusiveness of the idea of the state, and the difficulty of identifying it with anyone or anything in particular (Runciman 2003), sets the ground from which the state seeks to constitute itself as a sovereign entity through symbolic and discursive representations that function to define and stabilise the very meaning of sovereign power and authority, though these meanings vary historically (Weber 1995). In this conceptualisation, the state is both as a system - 'a palpable nexus of practice and institutional structure', and an idea - a historically constructed and contested 'exercise in legitimation, in moral regulation' (Abrams 1988:82, 81; Mitchell 1999). I propose that the state be studied as, simultaneously, a coercion-yielding entity, essentially characterised by its ability to maintain a monopoly over the use of violence; as a cultural institution of moral regulation encapsulated within historically constructed yet enduring narratives about the state; and a sociological institution wherein groups and individuals with particular class, religious, and social interests vie with each other for power, authority, and/or legitimacy (Weber 1978; Corrigan and Sayer 1985). Theories that either tend to primordialise the nation, or view the emergence of nationalisms and their attendant exclusions independently of processes of state formation, elide the way mechanisms of state building, nation formation, and construction of national 'others' are conjoined, and how interactions among them give historically varying responses to the very basis of 'national identity'.

Recently, a growing body of literature has convincingly revealed how identities, attachments, and minorities are culturally and politically created, changing in time and place (e.g. Chatterjee 1993; Alonso 1994; Burguiere and Grew 2001; Kemper 1991; Van der Veer 1994). However, in contrast 
to Western European countries where understandings of citizenship and nationhood and processes of state-building have developed organically and culturally over the course of centuries (Brubaker 1992; Corrigan and Sayer 1985), similar processes in postcolonial countries have spanned much shorter time periods and have entailed, on the one hand, construction of new 'citizens' that were formerly relegated to the status of 'subjects' under colonial rule (Mamdani 1996), and on the other, continuation of colonial idioms of rule, often premised on the routinisation of violence (Chatterjee 2005; Pandey 2006). These states have, in other words, actively undertaken the task of the construction of the 'nation form'. Categories and distinctions of caste, religion, and ethnicities that were constructed under colonial rule survived into the post-colonial period had now to be re-negotiated afresh. I contend that it is in this re-negotiation of the boundaries of the nation that new social imaginaries of the nation-state are constructed, which in turn shape state practices and institutions of social closure through which the cultural inscription of the very idea of a sovereign state is secured.

\section{The Pakistani State and the Genealogy of the 'Ahmadi Question'}

The fundamental doctrinal difference between Ahmadis and Sunni Muslims, on the basis of which the Ahmadiyya community has historically been deemed heretical by orthodox Sunni Muslims, concerns the status of the founder of the Ahmadiyya sect, Ghulam Mirza Ahmad, who lived from 1835 to 1908 in the city of Qadian in colonial Punjab. The majority of Sunni Muslims believe that Mirza Ahmad was an apostate who claimed for himself Khatam-e-Nubuwwat, or, the status of the last divine prophet. Traditionally, Muslims believe that the Prophet Muhammad is the last prophet to be sent on Earth by God, thereby holding the seal of prophecy, a belief that holds central place among Islamic religious precepts and any suggestion to the contrary is perceived to be blasphemous. The opinion among the Ahmadis on the status of Mirza Ahmad differs. ${ }^{2}$ While one prominent group, headed by the Jamaat-e-Ahmadiyya (based initially in the city of Rabwah in Pakistan and presently in London, U.K.) believes Ghulam Mirza to be a divine prophet who had heard and responded to divine revelation, the other, popularly termed the Lahori Jamaat because of the group's establishment in the city of Lahore in Pakistan, denies this charge and claims that Ghulam Mirza was merely a sacred and holy man of God without having prophetic status. In popular mainstream narratives, however, such internal distinctions are often overlooked and all Ahmadis collectively referred to as Mirzais (followers of Mirza) or Qadianis (from Qadian), words that have over time taken on intensely derogatory connotations. 
The constitutional amendment of 1974 was a clear departure from the Pakistani state's earlier stance towards the larger issue of the state's role in the definition of the boundaries of Muslim citizenship. Anti-Ahmadiyya movements have a long history in Pakistan. Even before the creation of Pakistan, right-wing religious groups, most notably Majlis-i-Ahrar-i-Islam, were agitating against the Ahmadis, portraying them as heretics. ${ }^{3}$ However, when Muhammad Ali Jinnah, considered the founder of Pakistan and who later became the country's first Governor-General, was asked to comment on the religious status of the Ahmadiyya community by a journalist during a press conference in 1944, three years prior to the independence of Pakistan, Mr. Jinnah observed, 'Who am I to declare a person non-Muslim who calls himself a Muslim?'4 By popular Ahmadi accounts, Jinnah invited the community to migrate to Pakistan at the time of the partition, and assured the Ahmadis that their rights as full citizens of Pakistan would be fully protected. ${ }^{5}$

In independent Pakistan, the demand that the Ahmadiyya community be declared non-Muslim was first publicly made in 1949 by the Ahrar in public meetings throughout the province of Punjab, with the support of numerous religious organisations. Earlier the same year, the Ahrar Party announced that it was changing its status from a political establishment to a religious one, declaring at the same time its allegiance with the Muslim League, the ruling party in the province of Punjab, in all political matters (Lahore High Court 1954:13). Perhaps the most important event that explains the timing of the Ahrar demands is the passing of the Objectives Resolution in March 1949, a resolution on the 'Aims and Objects of the Constitution', akin to a preamble. The Resolution and the debates surrounding this Resolution are of immense importance for situating these anti-Ahmadiyya demands. While the Resolution refrained from naming Pakistan an 'Islamic state', it began by vesting 'sovereignty over the entire universe' to God, and clearly laid down that it was a state 'Wherein the Muslims shall be enabled to order their lives in the individual and collective spheres in accordance with the teachings and requirements of Islam as set out in the Holy Qur'an and the Sunnah'. In the very next sentence, the Resolution goes on to assert that the rights of all minorities with regard to freedom of faith, association, cultural expression, and equality would be fully protected. During the Constituent Assembly debates on the Resolution prior to its passing, the non-Muslim members of the Constituent Assembly raised vehement objections with regard to the usage of Islamic terminology in the Resolution, and proposed a number of amendments that would further safeguard the rights of minorities in Pakistan. The motion to amend the Objectives Resolution was denied (Khan 2005). 
The allegiance of the state to Islam at this crucial moment gave the Ahrar leadership impetus to make their anti-Ahmadiyya demands public (Nasr 1994). However, at this moment, despite the state's nominal affiliation with the symbols of Islam in the Objectives Resolution, the state remained committed to protecting the fundamental rights of all religious minorities, and deemed the anti-Ahmadiyya campaign of the Ahrar unlawful (Lahore High Court 1954).

Anti-Ahmadiyya agitation broke out again in 1953 in the province of Punjab, again led by the Ahrar, but this time with the support of the ruling party in Punjab, in particular its Chief Minister Mumtaz Daultana, and the Islamist political party Jamaat-e-Islami. On 21 st January 1953, an ultimatum was delivered to the Prime Minister of Pakistan by a delegation of ulama (religious leaders) to the effect that if the state did not declare the Ahmadiyya community non-Muslim and remove all Ahmadis from key posts in the state, their parent organisation, Majlis-i-Amal, would resort to direct action against the government. A little over a month later, the government rejected the ultimatum and authorised the arrest of prominent members of Majlis- $i$ Amal. In the wake of widespread anti-Ahmadiyya agitation and violence that ensued, the state authorised the arrest of prominent religious members, most notably Maulana Maududi, the founder of Jamaat-e-Islami, and another of its prominent members, Maulana Kausar Niazi. Both were later charged with treason and imprisoned for inciting violent sectarian feelings through giving public speeches and distributing objectionable literature (Ali 2002:178). The state ultimately declared Pakistan's first Martial Law over the city of Lahore, and proceeded to violently repress right-wing agitators. In 1954, the committee set up by the state to inquire into the disturbances noted in its final report the importance of the question of Muslim identity for the newly formed Pakistani state but concluded that question of who was and wasn't a Muslim was almost impossible to decide, further noting that the ulama themselves 'hopelessly disagreed among themselves' on this fundamental question (Lahore High Court 1954:205). The report forcefully upheld the importance of individual conscience in religious matters along with that of full citizenship rights, and declared that the riots had been instigated by radical Islamic groups in conjunction with the ruling party in Punjab to deliberately cause disturbances. I term this moment in the genealogy of the relationship between the Ahmadiyya community and Pakistani state as the moment of accommodation.

The 'Ahmadi question' emerged on the national scene again in 1974. On 30th July 1974, all major newspapers reported that a group of 160 non-Ahmadi Muslim students of Nishtar Medical College, Multan (NMC) were attacked 
on the Train Station at the city of Rabwah, a predominantly Ahmadi town, by thousands of Ahmadis. According to the newspaper, the crowd was armed with sticks, knives, and swords, and proceeded to attack and beat the students, injuring 30 in the process. During the subsequent investigations, the number of attackers and those hurt, and the nature and the reasons for the attack would come under inquiry. However, it was acknowledged by all that on 22nd May, when the same students had stopped at Rabwah train station, there had been some minor skirmish between a group of Ahmadi and non-Ahmadi students, with the former claiming that anti-Ahmadiyya slogans had been shouted without provocation, and the latter denying those claims.

In response to the incident, acts of violence against the Ahmadiyya community started immediately, especially in the province of Punjab. At various university campuses, Ahmadi students were forcibly thrown out of their hostel rooms, their belongings collected and set on fire. Ahmadi shopkeepers in markets and bazaars started receiving threatening phone calls while enraged crowds stoned and burned Ahmadiyya shops, gas stations, and factories. Incidents of beatings of Ahmadis were reported which, according to official reports, also led to forty-two murders, of which twenty-seven were reported to be of Ahmadis (Dawn Newspaper, Karachi: 23rd June 1974). Violence against the Ahmadiyya community came to an end within a week, largely because of willingness on the part of the state to use force to curb violence. However, a propaganda campaign was launched, with major Islamist political parties, religious organisations, student and trade unions; as well as members of opposition parties in the national and provincial assemblies, and public intellectuals publicly demanding that the government declare the Ahmadiyya community a non-Muslim minority; remove all Ahmadis from key positions in state institutions; and that it declare Rabwah, alleged a 'state within a state' run by the despotic descendents of Ghulam Mirza Ali, an 'open city'. Additionally, a nationwide movement was launched that advocated the social boycotting of the Ahmadiyya community. The following announcement that appeared on the front page of Nawa-e-Waqt, a major national newspaper that supports the religious Right, is typical of the scores of statements and announcements that were being sent in to and published by newspapers:

It is the Religious Duty of all Muslims

That the Deniers of the Finality of the Prophethood of Prophet

Muhammad (PBUH),

the Qadianis, be completely boycotted,

That they [the Muslims] maintain no relationships with them [the

'Qadianis'] and do not buy and sell products made by them. 
We strongly demand from the Prime Minister of Pakistan Mr. Zulfiqar Ali Bhutto that he, without delay,

Declare the Qadianis a non-Muslim minority

And on the Day of Judgment, with the Shafa'at [intercession] of the Last of the Prophets PBUH, earn a high place in Heaven.

From: President Wholesale Cloth Association, Gujranwala

And Khwaja Cloth Market, Insaaf Cloth Market, Khaqwani Cloth

Market, Madina Cloth Market [...etc]

(Nawa-e-Waqt Newspaper, Lahore: 16th June 1974, translated by author)

In response to anti-Ahmadi violence and propaganda, the state immediately sprang to attention in a bid to retain its loosening grip on what it called 'the law and order' situation. ${ }^{6}$ Over the course of a few days, the government started curbing anti-Ahmadi processions, arresting prominent student and religious leaders on the grounds that they were fuelling sectarian and communal riots, and placed a ban on the publishing of sectarian news. The state also arrested seventy-one Ahmadis for their alleged involvement in the attack of 29th May and appointed a Lahore High Court judge to investigate the incident and submit his findings.

On 13th June, in response to the call for a General Strike by right-wing religious organisations, Bhutto in a televised speech announced that the Ahmadi issue would be placed before the National Assembly for deliberation (Dawn Newspaper, Karachi: 14th June 1974). Bhutto was urged to take this course of action by his Minister of Information, Kausar Niazi, the same man who had been behind the 1954 anti-Ahmadiyya agitations, then a member of the Islamist party Jamaat-i-Islami, and in 1974 of Bhutto's People's Party. The National Assembly was subsequently converted into a Special Committee which debated the issue of whether the Ahmadiyya community was a Muslim or not, and called the various heads of Ahmadiyya organisations to present their views and to answer questions posed by members. The exact proceedings of these deliberations have not been made public to this day. The Ahmadiyya community was unanimously declared a non-Muslim minority and the second constitutional amendment passed by the National Assembly on 7th September. I call this phase the moment of exclusion with regard to the relation between the state and the Ahmadiyya community.

It was this moment of nationalist exclusion that set the grounds for a subsequent legislation that made it a criminal offence for Ahmadis to refer 
to themselves as Muslims. In 1984, a group of religious leaders issued an ultimatum to the government of military General Zia-ul-Haq, who had acceded to power through a military coup in 1977, demanding the immediate removal of all Ahmadis from key posts in the state; the arrest of the spiritual head of Ahmadiyya community in Pakistan; identification of Ahmadis as 'non-Muslims' on identity cards and passports; and demolition of all places of Ahmadiyya worship (Kaushik 1996). The Zia regime, needing no further ammunition, immediately promulgated an ordinance that prohibited Ahmadis from 'posing as Muslims' by using Islamic symbols and nomenclature in describing their religion or places of worship, making it a crime punishable by death, imprisonment, and/or heavy fines (Pakistan Penal Code 1984). Titled the Anti-Islamic Activities of the Quadiani Group, Lahori Group and Ahmadis (Prohibition and Punishment) Ordinance (1984), this repressive legislation had the effect of making the Ahmadiyya community a target of continued harassment, as a result of which the community has retreated almost completely from public life in Pakistan, living in continuous terror of the state. ${ }^{7}$ I call this moment the moment of criminalisation of the Ahmadiyya community. ${ }^{8}$

\section{The Pakistani State and the Formation of a New Religious Minority}

While much emphasis has been laid on aspects of Ahmadiyya religious thought in theory and practice (Spencer 1974; Friedmann 1989; Gualtieri 2004) and the documentation of marginalisation of the community by the Pakistani state through both legal-constitutional and extra-legal means (Gualtieri 1989; Kaushik 1996; Khan 2003), there is no systematic study of the socio-political contexts that have given rise at different times to different responses by the state towards the religious status of the Ahmadiyya community. 1974 constituted a moment in Pakistan's history in which the margins of the 'Muslim nation' were symbolically (re)constructed to exclude the Ahmadiyya community from the boundaries of Muslim citizenship. As anti-Ahmadiyya agitation continued to grow in 1974, the state was confronted with a choice: to revert to its historical precedent of cracking down on right-wing establishments to thwart anti-Ahmadiyya demands, or to engage somehow with these demands. The first option wasn't a possibility in 1974 for a number of reasons. Firstly, the political climate in 1974 was radically different from that in 1954. The socialist government of Zulfiqar Ali Bhutto had been ushered in in 1971, in the wake of Pakistan's war with India that had resulted in Pakistan losing one half of its territory through the creation of the independent state of Bangladesh. Following this monumental event, questions about the very identity of the nation-state of Pakistan 
resurfaced, which resulted in the socialist regime identifying itself closely with Islam. For example, Bhutto characterised his regime as an 'Islamic socialist' one, and during the 1970s, instituted a number of legislations to impose an Islamic moral order. ${ }^{9}$ This alliance between religion and the left would prove crucial for the fate of the Ahmadiyya community. One of the first significant manifestations of this alliance, however, was the Constitution of 1973, in which Islam for the first time in the history of Pakistan was declared the 'state religion'.

Secondly, the scale of anti-Ahmadiyya nationalism was much larger in 1974 than it had been in 1954. Oral accounts of the time period suggest that that country was gripped in anti-Ahmadiyya fervour and the pressure on the state to act according to popular nationalist demands was intense. Indeed, the demands were couched within rhetoric of democracy, with various organisations, opposition members, and newspapers demanding that the state act in a democratic manner and in accordance with the wishes of the majority of the nation. The state response in 1954 was cited as an instance of state repression.

In 1953-54, the state's response to anti-Ahmadiyya nationalist violence produced a number of 'state effects' through which both state power and the idea of the state were institutionalised and articulated (Jessop 1990; Trouillot 2001). Firstly, the state in an unprecedented move, that was also clearly unconstitutional, by-passed both the elected federal and provincial governments, took recourse to martial law thereby institutionalising a new language for governance to regulate the body politic in the name of the maintenance of law and order. Secondly, while the state engaged with the issue of defining the boundaries of 'Muslim citizenship', it ultimately proposed a territorial, and not a religious, conception of the nation, while recognising that the majority of the citizens of Pakistan were Muslim. Lastly, the idea that it was the institution of the state, and not those of elected representatives, which could most effectively guarantee rights and just outcomes in a clash between different ideas about national minorities was implicitly professed by the state, with the state distrusting elected representatives as being partisan, biased, and intent upon embarrassing the state.

In 1974, all of these aspects were brought under critical scrutiny. This time, anti-Ahmadiyya demands were couched within public narratives about the state - its functions, its ideology, its responsibility to the majority of Pakistanis, its relationship to Islam, etc. For example, it was being claimed across the board that the basis of the origins of Pakistan were founded on 
Islam, and that Islam alone provided justification for the existence of an independent Pakistan. The history of Pakistan reveals a fundamental tension between these two competing ideas about the Pakistani state - Pakistan as an Islamic nation-state, meant to serve the Islamic moral community, or Pakistan as a liberal-secular state, that at best will pay lip-service to Islam but will, for all practical purposes, be divorced from religious precepts (Cohen 2004).

Stephen Cohen observes that 'the most important conflict in Pakistan is not a civilisational clash between Muslims and non-Muslims, but a clash between different concepts of Islam, particularly how the Pakistani state should implement its Islamic identity' (Cohen 2002:113). Nowhere is this more visible than the Pakistani state's relationship with the Ahmadiyya community. The 'Ahmadi question' at this moment proved to be the means through which the Pakistani state was historically reconstituted, both institutionally and discursively, in order to provide a different solution to the problem of accommodating Islam within the national narrative. The wider social base of the anti-Ahmadiyya nationalism in 1974, coupled with the increasing presence of religious rhetoric within the Bhutto regime, created the space within which the state was led to revise its earlier position on the 'Ahmadi question'.

In the construction of this new national narrative, the 'history' of the formation of the Ahmadiyya religion occupied centre stage. One of the most vocal and public articulators of the 'history' of Ahmadiyya community in Pakistan at the time was the journalist and public intellectual Z. A. Suleri, who, in a series of articles published in Nawa-e-Waqt, a right-wing Urdu language national newspaper, popularised his views. With regard to the birth of the Ahmadiyya religion in the late nineteenth century Punjab, Suleri argues that the Ahmadiyya religion was given patronage by the British colonial authorities because of its anti-Jihadi (Holy War) and pacifist teachings in order to create a band of loyal Muslims who did not see it as their religious duty to oppose British colonial rule ${ }^{10}$ (Nawa-e-Waqt Newspaper, Lahore: 30th June 1974). In one of his earlier articles, Suleri celebrated the Rabwah incident as 'a blessing in disguise' for throwing into 'bold relief the truly religious character of Pakistani society' (Nawa-e-Waqt Newspaper, Lahore: 23rd June 1974). A staunch critic of Bhutto and his socialism, Suleri equated the religion of the 'Qadianis' with the 'communist materialist creed', and pronounced both an 'anathema to the Islamic way of life' (ibid.). Suleri argued that the creation of Pakistan was fundamentally premised on Muslim nationhood, a position that was rejected by the Ahmadiyya community at the time of the Pakistani movement. Furthermore, Suleri argued, Islam alone 
could offer a unifying point of departure for the nation. It was the failure to recognise the fundamental importance of Islam for Pakistan nationhood that had led to the separation of East Pakistan (later Bangladesh) from Pakistan. (Nawa-e-Waqt Newspaper, Lahore: 23rd June 1974)

The position that the Ahmadiyya community was linked to foreign elements that were antithetical to the Pakistani state was seriously entertained by the Pakistani state itself. The proceedings of the tribunal constituted by the Punjab government, to be headed by the Lahore High Court Judge K.M.A. Samdani, to investigate the disturbances of 29th May, provides an especially rich source for analysing how both the Pakistani state and rightwing nationalists articulated the Ahmadi issue. ${ }^{11}$ In addition to the state, the tribunal allowed different religious organisations and the Ahmadiyya community to present their views and testimonies regarding the 29th May event. The organisations represented in the tribunal included, among others, Jamaat-i-Islami; Majlis-i-Tahaffuz-i-Khatm-i-Nabuwwat (Assembly for the Protection of the Finality of Prophethood; MTKN); the Ahmadiyya organisation of Rabwah; the Student Union of Talimul Islam College, Rabwah, whose students were allegedly responsible for the 29th May attack; and Jamiat Ulema-e-Pakistan (Assembly of the Pakistani Ulama). The 'Rabwah Tribunal' commenced its proceedings on 4th June 1974 and brought them to an end on 3rd August 1974. During this inquiry into the 29th May incident, the tribunal recorded testimonies of seventy persons, both Ahmadis and non-Ahmadis. In addition, some people sent in written records that were made part of the tribunal record. Most of the tribunal proceedings were held in open court, with newspapers publishing these almost on a daily basis (Dawn Newspaper, Karachi: 4th August 1974). While most of the inquiry revolved around the 29th May event, questions about the administration of Rabwah, the loyalty of the Ahmadiyya community to Pakistan, and its religious status and beliefs were also raised and debated.

Regarding the event itself, different eye-witnesses and participants, both Ahmadis and non-Ahmadis were called in to give their account of the event. The Ahmadiyya student body maintained that they had been provoked into the fight by the NMC students, who at the Rabwah train station earlier on 22nd May had shouted offensive slogans at the Ahmadiyya students in the ground nearby, in addition to verbally sexually harassing a group of girls at the station. The NMC students denied these charges, instead claiming that the attack had been unprovoked, and that it was the Ahmadiyya students who had shouted blasphemous slogans on 22nd May and had tried to distribute objectionable Ahmadiyya literature to the NMC students. This line of inquiry was mostly concerned with ascertaining the number of attackers, their 
identities, the methods of attack, the timing and, in short, the logistics of the attack. Throughout the inquiries, however, the non-Ahmadiyya side was given more space and time to articulate and debate their position. It was charged again and again that the attack was pre-planned, unprovoked, authorised by the Ahmadiyya administration of Rabwah, and part of a larger strategy to overturn Islam and institute the Ahmadiyya religion in Pakistan.

The religious organisations in fact announced that they were unable to represent their case with regard to the complicity of the Ahmadiyya Jamaat without debating the larger issue of the religious status of the Ahmadiyya community (Nawa-e-Waqt Newspaper, Lahore: 16th June 1974). Justice Samdani asserted that the tribunal's position was that the Ahmadiyya community did form a distinct sect having its own organisational structure, and that the issue of the basis of their separateness from the rest of the community was relevant to the case. Despite protests by the lawyer of the Ahmadiyya Jamaat of Rabwah that the issue of the religious beliefs of the community was irrelevant to the case in hand, the tribunal asked all the lawyers to prepare written statements regarding the issue of the basis of Ahmadiyya separateness (ibid.). While the issue wasn't openly debated during the inquiry, the religious establishments in their concluding statements demanded that the tribunal in its final report recommend that the community be declared non-Muslim (Nawa-e-Waqt Newspaper, Lahore: 4th August 1974).

While the exact status of the Ahmadiyya community was not discussed, the 'heretical' and 'blasphemous' practices of the community were neatly threaded in with discussions about the organisation of the Ahmadiyya Jamaat in, and their administration of, Rabwah. Witnesses were brought in who gave statements regarding the despotic nature of the Jamaat in Rabwah, particularly the close family and associates of the Khalifa - the head of the Jamaat and the direct descendent of Ghulam Mirza. For example, a Mohammad Saleh Nur, an Ahmadi by birth who was later dislodged from Rabwah in 1956, claimed that he and fifty others were shunned that year on grounds of making critical statements about the Khalifa (Nawa-e-Waqt Newspaper, Lahore: 27th June 1974). In addition to being fired from his job, he was made to leave Rabwah without his wife and children, who were kept away from him on the grounds that since he was no longer an Ahmadi, he had no claim on his Ahmadi family. Several such witnesses and ex-Ahmadis were brought in who gave testimonies to the effect that the Jamaat had its own system of administration, education, policing, and justice, all characterised by despotism and arbitrariness, and which by-passed the state altogether. Furthermore, it was stated that the Jamaat had formed 
quasi-militias in Rabwah that were armed and ready to strike out against the 'Muslims' in Pakistan, with the help of foreign enemies. For example, the lawyers representing the MTKN argued that the 29th May incident was a part of a larger 'Qadiani' conspiracy to collaborate with India to create a 'united India' in the South Asian sub-continent (Nawa-e-Waqt Newspaper, Lahore: 20th June 1974).

On 20th August 1974, K.M.A Samdani presented a 112-page report to the Punjab government (Dawn Newspaper, Karachi: 21st August 1974), which was later passed on to the National Assembly to assist in deliberating the 'Ahmadi question'. The contents of the report, along with the National Assembly proceedings, have not been made public to this day. The proceedings of the tribunal, however, which were open to public viewing were being published and sensationalised in newspapers, had the effect of creating a paranoiac response among Pakistani nationalists, especially given the international context of India's successful nuclear testing earlier in the year and of fresh memories of Indo-Pakistan war of 1971 which was held to be the primary cause of the separation of East Pakistan (later Bangladesh) from Pakistan. In view of intense anti-Ahmadiyya propaganda, coupled with the critique of the state that was weaved in through an emerging nationalist narrative, the state revised its earlier position that the question of the boundaries of Muslim citizenship was a religious and not a political matter. Appropriating rhetoric of democracy and Islam, the socialist regime of Prime Minister Bhutto gave a new response to the spiritual-symbolic contours of the nation in a bid to retain a semblance of legitimacy for the state, thereby fundamentally changing the course of state formation in Pakistan.

\section{Conclusion: Assessing 1974}

1974 constituted a moment in Pakistan's history in which the margins of the 'Muslim nation' were symbolically (re)constructed to exclude the Ahmadiyya community from the boundaries of Muslim citizenship. I have examined the tribunal investigations of the Lahore High Court to show how the Ahmadiyya community was symbolically constructed not only as heretic but also as disloyal and traitorous, the enemy within, which had to be curbed by the state in order for the dream of independence from colonial rule to be realised. In an important sense therefore, the Ahmadiyya issue is fundamentally a post-colonial one, where the 'post' implies that the present can only be understood in relation to the (perceived) past. In the 'state space' constituted by the tribunal investigations, what was questioned was not only the religious status of the Ahmadiyya community, but also the role of the nation-state in curbing the threat to the moral community of the nation. The 
second constitutional amendment of Pakistan, arrived at through supposedly democratic means (since the issue was eventually decided on by the elected majority in the National Assembly ${ }^{12}$ ), recalls Giorgio Agamben's thesis that the subjection of biological life to authoritarian and illiberal practices of death, torture, and exclusion emerges from the very core of, or is the very basis of, the liberal democratic order (Agamben 1998). The use of law to legally enact sanctions against the Ahmadiyya community served to resituate the state as the primary institution of moral regulation (Corrigan and Sayer 1985), with the power to articulate and instate the 'exception', which, according to Agamben, is always founded upon the exclusion of 'bare life', or simple biological life, the figure of which is historically varying. In the case of the Pakistani state, this figure came to be embodied by the Islamic 'heretic' who quite literally had to be disciplined into shedding Islamic symbols from their public religious practices. Furthermore, the events leading up to the amendment throw light on the ways in which the question of boundaries - between the centre and periphery, public and private, lawful and un-lawful - were debated, re-drawn, and re-inscribed in the nationalist narrative. A focus on the historical constitution of such boundaries, especially through a focus on the 'margins' suggests, as Das and Poole observe, that 'such margins are a necessary entailment of the state, much as the exception is a necessary component of the rule' (Das and Poole 2004:4).

The Pakistani state has, over the course of its history, negotiated the question of the boundaries of the Pakistani nation in different ways at different times. The key to answering this question of the state's changing relationship to Islam in defining the contours of 'Muslim citizenship' cannot simply be located by looking at articulations of nationalism in the body politic and locating the symbolic construction and institutional discrimination of minorities in the 'evils' present in all modern nationalisms (Kedourie 1960), more specifically religious or ethnic-based nationalisms. Scholarship that engages with public visibility of Islam in states such as Pakistan by attributing it to a lack of secularisation ends up regarding 'Islam' as a monolithic religion supporting an ahistorical system of thought that is perceived to be easily locatable through a highly limited nexus of 'Islamic' discourses and practices. The main problem with this position is that even the most seemingly entrenched and doctrinal Islamic laws in fact are socially constructed and emerge from historical contexts of power relationships and social structures of authority and domination (Zubaida 2004). Thus, the dichotomy between religious and secular discourses is misleading since so-called secular discourses may be intimately informed by religious motivations while religious texts always go through interpretation and human agency (An-Na'im 1995). Rather, I have 
argued for the importance of examining how the very idea of the Pakistani state, and especially its relationship to the 'heretic' others of the Pakistani Muslims, was contested and negotiated by different actors in the imagined political community of the nation.

\author{
Notes \\ ${ }^{1}$ The interpretation of the amended clause 260 (3) read as follows: \\ In the Constitution and all enactments and other legal instruments, unless \\ there is anything repugnant in the subject or context \\ (a) 'Muslim' means a person who believes in the unity and oneness \\ of Almighty Allah, in the absolute and unqualified finality of the \\ Prophethood of Muhammad (peace be upon him), the last of the prophets, \\ and does not believe in, or recognise as a prophet or religious reformer, \\ any person who claimed or claims to be a prophet, in any sense of the \\ word or of any description whatsoever, after Muhammad (peace be \\ upon him); and \\ (b) 'non-Muslim' means a person who is not a Muslim and includes \\ a person belonging to the Christian, Hindu, Sikh, Buddhist or Parsi \\ community, a person of the Quadiani Group or the Lahori Group who \\ call themselves 'Ahmadis' or by any other name or a Bahai, and a person \\ belonging to any of the Scheduled Castes. (Constitution of Pakistan \\ 1974)
}

${ }^{2}$ See Friedman (1989) for an appraisal of Ahmadiyya religious thought.

${ }^{3}$ Virtually from the beginning of their formation in 1931, the Ahrars had launched a public anti-Ahmadi campaign, demanding in 1934 that the community be declared outside the pale of Islam and that no Ahmadi be appointed to a public office, the latter being a direct reference to Zafarullah Khan, a prominent Ahmadi personality who was later appointed the first Foreign Minister of Pakistan. In this, the Ahrar party was ideologically close to the Punjab wing of the Muslim League, which too had declared the Ahmadiyya community non-Muslim and barred them from membership, even though the central wing of the League remained evasive on the issue (Friedman 1989: 37-38). During the anti-colonial movement, the Ahrar Party eventually aligned itself with the Indian National Congress and openly opposed the movement for the creation of an independent Pakistan.

${ }^{4}$ Quoted in Rashid Tasir, Tahrik-i-hurriyat-l Kashmir. Vol. 2. Srinagar: Muhafiz Publications, 1973, p. 291 (translated by author). Revisionist historiography on Jinnah is increasingly beginning to challenge the Pakistani state's narrative of Jinnah as committed to an independent state of Pakistan. For example, Ayesha Jalal (1985) argues that Jinnah did not abandon the image of India as a homeland for both Hindus and Muslims until 1946. Other scholars have showed that the vision of the Pakistani state that Jinnah envisioned was premised on a secular constitutional-democratic order (Ahmed 1997).

${ }^{5}$ Despite their decision to move to Pakistan after the partition, the Ahmadiyya community remained ambiguous and fearful towards the prospect of an independent Pakistan until the very end, as can be witnessed by the community's decision to avoid settling in major cities, where they would have become the sure targets of right-wing militant organisations. Instead, the community chose to settle in Rabwah, an undeveloped land situated ninety-five miles west of Lahore bought from the government, and soon declared it to be their spiritual headquarters in the world. Here, the community proceeded to set up its own administrative, educational, and social infrastructure with relative autonomy until 1974, when this autonomy, and its 
attendant institutions, were brought under crucial scrutiny by the state.

${ }^{6}$ See Dawn Newspaper, Karachi dated 1st June 1974 and 5th June 1974 for Punjab Chief Minister Hanif Ramay's initial public statements on the Rabwah incident to this effect.

${ }^{7}$ A number of NGOs have been documenting the severe breach of human rights with regard to the Ahmadiyya community in Pakistan. These include the Human Rights Watch, Amnesty International, and the Human Rights Commission of Pakistan. Visit www.thepersecution. org for an excellent overview of the reports published by these NGOs.

${ }^{8}$ The Ahmadiyya community challenged the ordinance in the Federal Shariat Court (FSC) on the grounds that it was against the injunctions of Islam and that it violated fundamental rights. The FSC Bench after lengthy deliberations declined the petition, arguing that the 1984 ordinance was in accordance with Islamic laws and principles. The Ahmadiyya community in turn challenged the FSC ruling in the Supreme Court (SC) of Pakistan where too the petition was defeated. The repressive ordinance of 1984 had the effect of making the Ahmadiyya community a target of continued harassment, as a result of which the community has retreated almost completely from public life in Pakistan. Countless number of people, both Ahmadis and non-Ahmadis, have been brought to local courts on grounds of blasphemy and for 'posing as Muslims' and have been put into jails and tortured while they awaited court decisions. The rights of assembly, expression, and speech have been curtailed by the state on countless occasions, most famously in 1989 when the Ahmadiyya community was banned from celebrating the 100 year anniversary of their religion. Again, this decision was challenged by the Ahmadiyya community in the Lahore High Court, where the appeal was dismissed.

${ }^{9}$ See Burki (1988) for an overview of political and social developments in Pakistan under Bhutto's regime.

${ }^{10}$ The editorial of Nawa-e-Waqt Newspaper (Lahore) unequivocally argued that the "Ahmadi problem' was a legacy and a reminder of colonial rule, and the problem would never have arisen if the Muslims had not been colonised. The editorial argues that under Muslim rule, no person would have dared to claim prophethood, for they would have known that such claims would not be tolerated (Nawa-e-Waqt Newspaper, Lahore: 2nd July 1974). Suleri's article in the same newspaper, in which he celebrated the passing of the second constitutional amendment, was tilted 'British Killed Today!' (Nawa-e-Waqt Newspaper, Lahore: 13th September 1974, translated by author)

${ }^{11}$ The 'Rabwah Tribunal' commenced its proceedings on 4th June 1974 and brought them to an end on 3rd August 1974. During this inquiry into the 29th May incident, the tribunal recorded evidence of seventy persons, both Ahmadis and non-Ahmadis. In addition, some people sent in written records that were made part of the tribunal record. Most of the tribunal proceedings were held in open court, with newspapers publishing these almost on a daily basis (Dawn Newspaper, Karachi: 4th August 1974).

${ }^{12}$ Dawn, the widest circulating English language newspaper in Pakistan, hailed the incidence of democratic triumph, observing that 'The manner in which the decision was taken augers well for the growth of democracy in the country. Constitutionality is the breath of life in a democracy. The same decision coming as an official decree would not have meant the same thing.' (Dawn Newspaper, Karachi: 10th September 1974)

\title{
References
}

\author{
Abrams, Philip. 1988. 'Notes on the Difficulty of Studying the State', Journal \\ of Historical Sociology 1, 1: 58-89.
}


Agamben, Giorgio. 1998. Homo Sacer: Sovereign Power and Bare Life. Stanford: Stanford University Press.

Ahmed, Akbar S. 1997. Jinnah, Pakistan and Islamic Identity: The Search for Saladin. London; New York: Routledge.

Ali, Tariq. 2002. The Clash of Fundamentalisms: Crusades, Jihads and Modernity. London; New York: Verso.

Alonso, Ana María. 1994. 'The Politics of Space, Time and Substance: State Formation, Nationalism and Ethnicity', Annual Review of Anthropology 23: 379-405.

Anderson, Benedict. 1991 [1983]. Imagined Communities: Reflections on the Origins and Spread of Nationalism. London; New York: Verso.

An-Na'im, Abdullahi. 1995. 'The Dichotomy between Religious and Secular Discourse in Islamic Societies', in Mahnaz Afkhami (ed.), Faith and Freedom: Women's Human Rights in the Muslim World. Syracuse University Press, pp. 51-60.

Appadurai, Arjun. 1981. 'The Past as a Scarce Resource', Man 16, 2: 201-219.

Balibar, Etienne. 2004. We, the People of Europe? Reflections on Transnational Citizenship. Princeton; Oxford: Princeton University Press.

Brubaker, Rogers. 1992. Citizenship and Nationhood in France and Germany. Cambridge, MA: Harvard University Press.

Burguiere, Andre and Grew, Raymond (eds). 2001. The Construction of Minorities: Cases for Comparison Across Time and Around the World. Ann Arbor: University of Michigan Press.

Burki, Shahid J. 1988. Pakistan under Bhutto, 1971-1977. London: Macmillan.

Chatterjee, Partha. 2005. 'Sovereign Violence and the Domain of the Political.' in Thomas Blom Hansen and Finn Stepputat (eds), Sovereign Bodies: Citizens, Migrants, and States in the Postcolonial World, Princeton; Oxford: Princeton University Press.

Chatterjee, Partha. 1993. The Nation and Its Fragments: Colonial and Postcolonial Histories. Princeton, N.J.: Princeton University Press.

Cohen, Stephen P. 2004. The Idea of Pakistan. Washington D.C.: Brookings Institution Press.

Cohen, Stephen P. 2002. 'The Nation and the State of Pakistan', The Washington Quarterly 25, 3: 109-122.

Constitution of Pakistan. 1974. Part XII, chapter 5, Article 260(3).

Corrigan, Philip and Derek Sayer. 1985. The Great Arch: English State

Formation as Cultural Revolution. Oxford: Blackwell.

Das, Veena and Poole, Deborah (eds). 2004. Anthropology in the Margins of 
the State. Oxford; Santa Fe: James Currey/School of American Research Press.

Dawn Newspaper, Karachi. April-September 1974.

Friedmann, Yohanan. 1989. Prophecy Continuous: Aspects of Ahmadi Religious thought and its Medieval Background. Berkeley: University of California Press.

Gualtieri, Antonio. 2004. The Ahmadis: Community, Gender, and Politics in a Muslim Society. Montreal; Kingston; London; Ithaca: McGill-Queen's University Press.

Gualtieri, Antonio. 1989. Conscience and Coercion: Ahmadi Muslims and Orthodoxy in Pakistan. Montreal: Guernica.

Hansen, Thomas Blom, and Stepputat, Finn. 2005. 'Introduction', in Thomas Blom Hansen and Finn Stepputat (eds), Sovereign Bodies: Citizens, Migrants, and States in the Postcolonial World, Princeton; Oxford: Princeton University Press.

Ignatieff, Michael. 1994. Blood and Belonging: A Journey into the New Nationalism. London: Vintage.

Jalal, Ayesha. 1985. The Sole Spokesman: Jinnah, the Muslim League, and the Demand for Pakistan. Cambridge: Cambridge University Press.

Jessop, Bob. 1990. 'Putting States in Their Place: Once More on Capitalist States and Capitalist Societies', in State Theory: Putting the Capitalist State in its Place. London: Polity Press.

Kaushik, Surendra Nath. 1996. Ahmadiya Community in Pakistan: Discrimination, Travail and Alienation. New Delhi: South Asia Publishers.

Kedourie, Elie. 1960. Nationalism. New York: Blackwell.

Kemper, Steven. 1991. The Presence of the Past: Chronicles, Politics, and Culture in Sinhala Life. Ithaca and London: Cornell University Press.

Khan, Hamid. 2005. Constitutional and Political History of Pakistan. Karachi: Oxford University Press.

Khan, Amjad Mahmood. 2003. 'Persecution of the Ahmadiyya Community in Pakistan: An Analysis under International Law and International Relations', Harvard Human Rights Journal 16: 217-244.

Kohn, Hans. 1944. The Idea of Nationalism: A Study in its Origins and Background. New York: Macmillan.

Lahore High Court. 1954. Report of the Court of Inquiry Constituted under Punjab Act II of 1954 to Enquire into the Punjab Disturbances of 1953. Lahore: Superintendent, Government Printing.

Mamdani, Mahmood. 1996. Citizen and Subject: Contemporary Africa and the Legacy of Late Colonialism. Princeton: Princeton University Press. Mann, Michael. 1986. 'The Autonomous Power of the State: Its Origins, 
Mechanisms and Results', in John A. Hall (ed.), States in History, New York: Blackwell.

Mitchell, Timothy. 1999. 'Society, Economy, and the State Effect', in George Steinmetz (ed.), State/Culture: State-Formation After the Cultural Turn, Ithaca, NY: Cornell University Press.

Nasr, Seyed Vali Reza. 1994. The Vangaurd of the Islamic Revolution: The Jama'at-i Islami of Pakistan. Berkeley; Los Angeles: The University of California Press.

Nawa-e-Waqt Newspaper, Lahore. April-September 1974.

Omi, Michael and Winant, Howard. 1994. Racial Formation in the United States: From the 1960s to the 1990s. $2^{\text {nd }}$ Edition. New York: Routledge.

Pakistan Penal Code. 1984. Ordinance XX.

Pandey, Gyanendra. 2006. Routine Violence: Nations, Fragments, Histories. Stanford: Stanford University Press.

Plamenatz, John. 1976. 'Two Types of Nationalism', in Eugene Kamenka (ed.), Nationalism: The Nature and Evolution of an Idea, London: Edward Arnold.

Runciman, David. 2003. 'The Concept of the State: the Sovereignty of a Fiction', in Quentin Skinner and Bo Straath (eds), States and Citizens: History, Theory, Prospects, Cambridge: Cambridge University Press.

Skocpol, Theda. 1979. States and Social Revolutions: A Comparative Analysis of France, Russia, and China. Cambridge: Cambridge University Press.

Spencer, Lavan. 1973. The Ahmadiyah Movement: A History and Perspective. Delhi: Manohar Book Service.

Steinmetz, George. 1999. 'Introduction', in George Steinmetz (ed.), State/ Culture: State-Formation After the Cultural Turn, Ithaca, NY: Cornell University Press.

Tasir, Rashid. 1973. Tahrik-i-hurriyat-I Kashmir. Vol. 2. Srinagar: Muhafiz Publications.

Tilly, Charles. 1985. 'War Making and State Making as Organized Crime', in Peter Evans, Dietrich Rueschemeyer, Theda Skocpol (eds), Bringing the State Back In, Cambridge: Cambridge University Press.

Trouillot, Michel-Rolph. 2001. 'The Anthropology of the State in the Age of Globalization', Current Anthropology 42,1: 125-38.

Van der Veer, Peter. 1994. Religious Nationalism: Hindus and Muslims in India. Berkeley; Los Angeles: University of California Press.

Weber, Cynthia. 1995. Simulating Sovereignty: Intervention, State and Symbolic Exchange. Cambridge: Cambridge University Press.

Weber, Max. 1978. Economy and Society, edited by G. Roth and C. Wittich. 
Berkeley: University of California Press.

Zubaida, Sami. 2004. Law and Power in the Islamic World. New York: I.B. Tauris.

Sadia Saeed is a doctoral student of Sociology at the University of Michigan, U.S.A. Her dissertation focuses on the role of religion in state formation and nation-building processes in Pakistan. 